\title{
УПРАВЛІННЯ ПОТОКАМИ ТВЕРДИХ ПОБУТОВИХ ВІДХОДІВ НА РІВНІ ТЕРИТОРІАЛЬНИХ ГРОМАД
}

\section{MANAGEMENT OF SOLID HOUSEHOLD WASTE FLOWS AT THE LEVEL OF TERRITORIAL COMMUNITIES}

\author{
Дзюбинська О.В., к.е.н., ст. викладач, Дзюбинський А.В., к.е.н., \\ доцент, Смаль М.В., к.т.н., доцент (Луцький національний технічний \\ університет)
}

Dziubynska O.V., Ph.D., Senior Lecturer, Dziubynskyi A.V., Ph.D., Associate Professor, Smal M.V., Ph.D., Associate Professor (Lutsk National Technical University)

Розглянуто проблему поводження з твердими побутовими відходами в територіальних громадах Волинської області. Проаналізовано стан охоплення населення роздільним збором ТПВ: спостерігається дефіциит об'єктів інфраструктури поводження з побутовими відходами; вивезенням сміття охоплено лише половину населення; об'єктами роздільного збирання відходів переважно є скло і пластик, а побутові відходи, в основному, захороняються на полігонах та звалищах. Особливо гостро проблема роздільного збору сміття постає в сільській місчевості, в зв'язку з чим запропоновано структуру логістичного ланцююга переробки відходів.

In the article is considered the problem of solid waste management in the territorial communities of Volyn region. The state of coverage of the population by separate collection of solid waste is analyzed: deficit of infrastructure facilities of household waste management is observed; only half of the population is covered by garbage removal; separate waste collection facilities are mainly glass and plastic, and household waste is mainly disposed of in landfills and dumps. The problem of separate waste collection is especially acute in rural areas, which is why the structure of the logistics chain of waste recycling is proposed.

In Ukraine, the predominant method of solid waste management is their storage at landfills. Land allocated for landfills already covers an area of more than 9 thousand hectares, and the need for new landfills is constantly growing. This indicates that the regions are losing the resource potential of household waste that is recyclable, whereas the processing enterprises of the industry lack raw materials.

The lack of a holistic system behavior with solid waste in the context of individual areas cannot be compensated by single attempts to organize the optimal collection and removal of garbage. Capital investments in certain parts of the chain logistics servicing of the solid waste flow will not improve the situation on a large scale. For example, some communities have the opportunity to invest in the purchase of specialized vehicles, but, at the same time, do not see the prospect of introducing a holistic model of garbage behavior. First of all, this is relevant for the united territorial communities, where there 
are no own options for waste disposal. That is, the issues of planning activities for garbage collection, transportation and processing should be comprehensive, and their decisions should be based on institutional capacity.

It is obvious that the creation of waste processing facilities in each community does not make economic sense, because, as practice shows, economic efficiency is not achieved immediately. Therefore, it is advisable to use the principle of clustering, so that the service area of the sorting line covers several settlements. The excretion of clusters and creation in each cluster the logistics systems servicing of waste collection and utilization will allow to optimize logistics flows.

The main role in the waste logistics development should be played the logistics infrastructure. Thanks to it, it is possible to prevent waste suitable for recycling and recovery from entering landfills and dumps. The effectiveness of its operation will be determined by the level of coverage of the population by the system of waste collection and separate collection in particular. One of the primary priorities of the logistics infrastructure development is the creation of collection points for secondary raw materials. The second priority is the organization infrastructure facilities network for treatment and recycling of household waste.

Ключові слова: побутові відходи, регіон, управління відходами, логістична мережа, кластери

Keywords: household waste, region, waste management, logistics network, clusters.

Постановка проблеми у загальному вигляді та їі зв'язок із важливими науковими чи практичними завданнями. В Україні переважаючим методом поводження з твердими побутовими відходами $\epsilon$ їх складування на полігонах. Землі, які відведені під сміттєзвалища вже займають площу понад 9 тис. га, а потреби в нових місцях захоронення постійно зростають. Це свідчить про втрату регіонами ресурсного потенціалу побутових відходів, що придатні для рециклінгу, в той час, як переробним підприємствам галузі не вистачає сировини.

Аналіз відомих досліджень і публікацій. Відсутність цілісної системи поведінки 3 твердими побутовими відходами (ТПВ) в розрізі окремих територій не спроможна компенсуватися поодинокими спробами організувати оптимальний збір та вивезення сміття. Капітальні вкладення в окремі частини ланцюга логістичного обслуговування потоку ТПВ масштабно не поліпшать стану справ. Для прикладу, окремі громади мають можливість вкладати кошти в закупівлю спеціалізованого автотранспорту, але, разом з тим, не бачать перспективи запровадження цілісної моделі поведінки зі сміттям. Насамперед це актуально для ОТГ, де немає власних варіантів для утилізації відходів. Тобто питання планування діяльності по збору, транспортуванні та переробці сміття повинні носити комплексний характер, а їх вирішення грунтуватися на інституційних можливостях. 
Питання управління побутовими відходами відображено в працях вітчизняних науковців: Р. Берлінг, О. Білопільської, Л. Бабаченко, В. Боронос, В. Голяна, К. Романова, І. Зварич [1], Р. Зварича, I. Коблянської, І. Колодійчук [2], В. Кравціва, Є. Мішеніна, О. Малєй, Н. Павліхи [3], М. Самойлік, П. Турчик та зарубіжних дослідників: A. Hanemaaijer, K. Haynes, A. Behrens, N. Millar, M. Hekkert, A. Murray, V. Rizos, J. Potting, K. Skene, E. Worrell, N. Van Buren [4] та ін.

Мета статті - вирішення проблеми поводження 3 твердими побутовими відходами на регіональному рівні.

Виклад основного матеріалу. Якщо враховувати заходи національної стратегії поводження з побутовими відходами [5], то ними передбачено забезпечення до 2023 р. переробки не менше 15\% побутових відходів, а до 2030 р. збільшення цього показника до 50 \%. Отже, до 2023 р. в Україні не передбачено заходів щодо підтримки системи роздільного збору ТПВ, бо вилучення з них ресурсоцінних компонентів на рівні $15 \%$ можливе за відсутності їх належного сортування. Тобто, наявна стратегія управління відходами не передбачає швидкого руху до моделі кругової економіки, тому необхідно більше уваги приділяти регіональним ініціативам, а особливо налагодженню потоків кругової логістики.

Очевидним $\epsilon$ те, що створення переробних потужностей ТПВ у кожній територіальній громаді не $є$ економічно вигідним, оскільки, економічна ефективність досягається не відразу. Тому, при формуванні потоків логістики відходів доцільно використати принцип кластеризації, а саме поширення зони обслуговування однієї сортувальної лінії на декілька населених пунктів. Таким чином, поділ території області на кластери та створення в кожному 3 них логістичних систем з обслуговування збору та переробки твердих побутових відходів дозволить оптимізувати транспортні потоки.

Схема поводження 3 побутовими відходами має складатися 3 фізичних i юридичних осіб, які безпосередньо задіяні у процесі поводження з ТПВ від часу їх появи до моменту переробки. Вона подана на рисунку 1 . Вивчаючи варіанти руху сміття, ми припустили:

1. Більшість операцій, що належать до відповідальності виробника, необхідно передати на аутсорсинг, наприклад особам, що займаються соціальним підприємництвом.

2. Досягнути роздільного збору ТПВ не можливо на початкових етапах функціонування логістики відходів, через що виникатиме потреба в наявності сортувальних станцій на полігонах та сміттєзвалищах.

3. Певну частку переробки вторинних ресурсів мають взяти на себе особи, які займаються малим підприємництвом.

4. Сортувальні станції, поряд з основним призначенням, паралельно необхідно використовувати для збору ресурсоцінних відходів. 


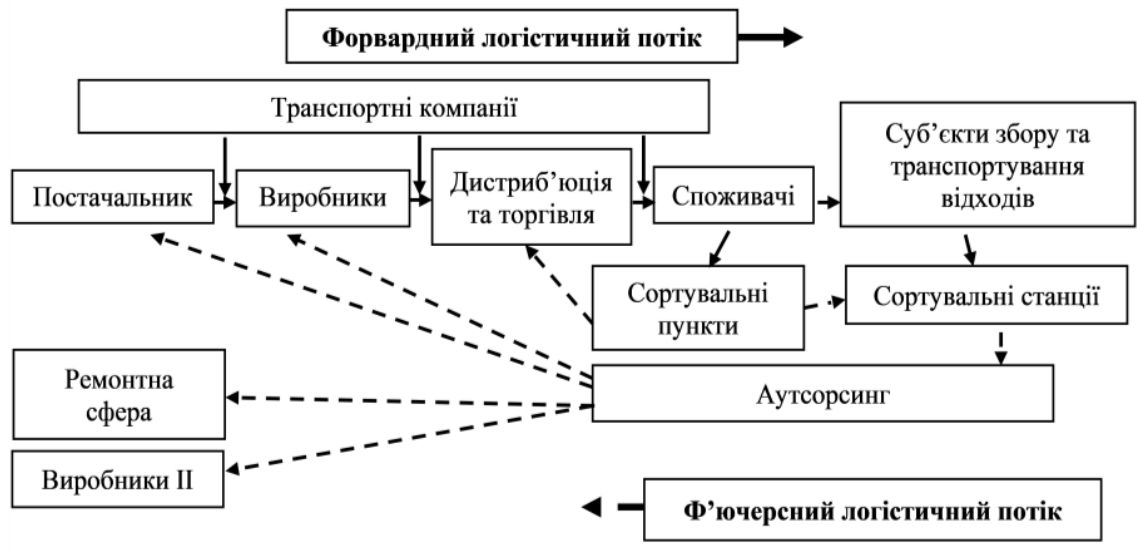

Рис. 1. Круговий логістичний ланцюг поводження з відходами [8]

Застосування відлагодженої схеми поводження з ТПВ є необхідною передумовою переходу до ефективного функціонування сфери переробки відходів. Однак, іiї відсутність або фрагментарність стають причиною виникнення значних перешкод для подальшого використання потенціалу вторинних ресурсів. Особливо актуальними ці моменти стають в час децентралізації, коли з'являються нові межі територій, що вимагає швидкого перегляду напрямів руху потенційних ресурсів. Формування ефективної логістики відходів гальмується ще й тим, що в невеликих населених пунктах ніколи не існувало повноцінної мережі, що обслуговувала б роздільний збір ТПВ.

Визначальну роль у функціонуванні логістики відходів має відіграти інфраструктура. Завдяки ӥй можна майже унеможливити потрапляння сміття, придатного для рециклінгу чи відновлення, на сміттєві полігони. Ефективність функціонування інфраструктури має визначатися часткою охоплення роздільним збором, що передбачає виділення ресурсоцінних елементів відходів (скло, папір, метал, полімерні відходи); біовідходів (рослинні та харчові); небезпечних елементів; специфічних відходів (ремонтних, великогабаритних, відходів електричного та електронного обладнання, батарей та акумуляторів, відпрацьованих батарейок). За цих умов, одним із головних пріоритетів існування інфраструктури логістики відходів має бути функціонування пунктів збору вторинних ресурсів. Іншою умовою $є$ існування мережі об'єктів переробки та обробки побутових відходів.

У багатьох регіонах України, зокрема і Волині, спостерігається дефіцит об'єктів інфраструктури логістики ТПВ. В середньому по області 
вивезенням сміття охоплено лише $52 \%$ фізичних осіб [6]. Винятком $є$ мешканці міст Луцьк та Ковель, де цей показник максимальний. Що стосується роздільного збору ТПВ, то воно зорганізоване лише у 88 населених пунктах (охоплення населення - $23 \%$ ) [7]. Найбільшим цей показник є у місті Нововолинськ (78 \%), далі йдуть Луцьк з 59 \% та смт. Маневичі - 54 \%. Головними об'єктами роздільного збору сміття $€$ пластик та скло. В області ТПВ, в переважній своїй більшості, захороняються на 478 сміттезвалищах, з яких тільки 23 \%, або 110 одиниць мають паспорти. Перевантажувальних станцій в регіоні немає, але функціонує 3 сортувальні лінії 3 річною продуктивністю 125 тис. т відходів: 2 - у місті Луцьк, третя розміщена в м. Ковель. В загальному, майже усе сортування ТПВ проходить вручну, де персонал тюкує ресурсоцінні відходи для відправки на переробні підприємства (зосереджені, в переважній більшості, у Луцькому та Ковельському районах).

Тобто найважливіші суб'єкти мережі поводження 3 відходами розташовані в області нерівномірно, що завдає проблем на локальному рівні. Такою локальною територією, що відчуває дефіцит інфраструктури поводження з відходами, наприклад, $є$ колишній Горохівський район (нині Луцький), де більшість населених пунктів перебуває в Горохівській, Мар'янівській та Берестечківській ОТГ. Функціональну схему пропонованої логістичної системи для цих громад відображено на рис. 2.

Пункти прийому вторсировини в сільській місцевості мають виконувати дві головні функції: інформаційно-контрольну та облікову. Перша передбачає, що працівники, які працюватимуть на цих пунктах матимуть комунікацію $з$ власниками відходів й доноситимуть інформацію про переваги роздільного збору сміття. Це стосується, насамперед, проблеми розділення відходів за видами (скло, полімери, метал, папір); чистоти вторинної сировини (забруднену важко реалізувати); вологості відходів (мокрі ресурси не переробляються). Зазначені критерії мають стати визначальними при прийманні відходів. Інша функція - облік видів та ваги ресурсів. Це необхідно для грошової компенсації здавачам. Забезпечувати роботу цих пунктів мають два працівники, а в населених пунктах до 100 жителів - один.

3 розвитком системи збору сировини й приймальних пунктів у сільських населених пунктах 800 та більше мешканців необхідно вводити додатковий персонал. 3 допоміжних засобів пункти першочергово мають бути обладнані роклами-вагами. Також необхідно планувати контейнери для роздільного збирання сміття - окремо для пластику, паперу та скла. Встановлювати контейнери необхідно в місцях масового скупчення школи, торговельні заклади тощо. 


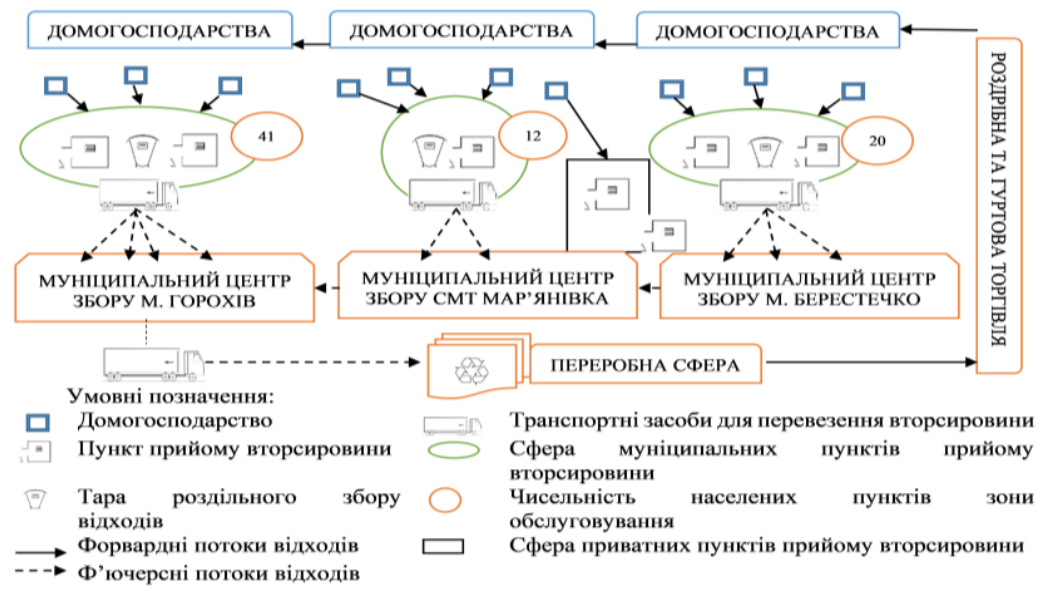

Рис. 2. Функціональна схема системи поводження з відходами на рівні ОТГ Волинської області [8]

В міру заповненості контейнерів, персонал пункту має доставляти їх для формування партій вторинних ресурсів. Сільські пункти дозволять створити комунікацію 3 територіальними муніципальними центрами збирання відходів. Крім того останні мають обслуговувати логістичні маршрути руху сировини з пунктів прийому до центрального пункту.

Висновки. Ми вважаємо, що зазначена схема збирання ресурсоцінних компонентів сміття у сільській місцевості має перспективу для існування. Відносно незначні об'єми відходів у порівнянні з містом та певна культура поводження з ТПВ (до прикладу, самостійне спалювання паперових відходів, застосування тари повторно для зберігання тощо) не потребують організації масштабного парку транспорту та контейнерів. Сільські приймальні пункти можуть працювати за принципом прийому відходів за місцем розташування, а не організовувати збирання по всьому селу. Планування цих пунктів можливе в приміщеннях закритого типу комунальної власності. Ф'ючерсні потоки сміття будуть організовані завдяки вивозом ресурсоцінних ТПВ по мірі завантаженості пунктів прийому відходами.

\section{References}

1. Zvarych I. Ya. (2017). Tsyrkuliarna ekonomika i hlobalizovane upravlinnia vidkhodamy [Circular economy and globalized waste management]. Zhurnal yevropeiskoi ekonomiky, 1 (vol. 16), 41-57. (in Ukrainian).

2. Kolodiichuk I. A. (2017). Zasadnychi pryntsypy formuvannia systemy povodzhennia $\mathrm{z}$ vidkhodamy [Basic principles of waste management system formation]. Rehionalna ekonomika, 2, 80-88. (in Ukrainian). 
3. Pavlov V. I., Pavlikha N. V., Skorokhod I. S. (2007). Efektyvnist vykorystannia vtorynnykh resursiv $\mathrm{u}$ rehioni: otsinka ta innovatsiini mekhanizmy [Efficiency of the use of secondary resources in the region: evaluation and innovation mechanisms]. Rivne. (in Ukrainian).

4. Van Buren N., Demmers M., Van der Heijden R., Witlox F. (2016). Towards a Circular Economy: The Role of Dutch Logistics Industries and Governments. Sustainability. Vol. 8. Retrieved from: https://www.mdpi.com/2071-1050/8/7/647\# (in English).

5. National Waste Management Strategy in Ukraine until 2030 : Order of the Cabinet of Ministers of Ukraine № 820-p (2019, December 24). Retrieved from: https://zakon.rada.gov.ua/laws/show/820-2017-\%D1\%80 (in Ukrainian).

6. Ministry of Development of Communities and Territories of Ukraine (2020). Stan sfery povodzhennia z pobutovymy vidkhodamy v Ukraini za 2019 rik [The state of the sphere of household waste management in Ukraine in 2019]. Retrieved from: https://www.minregion.gov.ua/napryamki-diyalnosti/zhkh/terretory/stan-sferypovodzhennya-z-pobutovymy-vi/ (in Ukrainian).

7. Chastka naselenykh punktiv, u yakykh vprovadzheno rozdilne zbyrannia TPV, u zahalnii kilkosti naselenykh punktiv rehionu [The share of settlements in which separate solid waste collection has been introduced in the total number of settlements in the region]. Retrieved from: https://www.minregion.gov.ua/wp-content/uploads/2018/01/Dodatok.pdf (in Ukrainian).

8. Dziubynska O. V. (2021). Mechanism of utilization of household waste resource potential of the region on the basis of a circular economy : PhD thesis abstract. Lutsk (in Ukrainian).

\section{Список використаної літератури}

1. Зварич I. Я. Циркулярна економіка і глобалізоване управління відходами. Журнал європейської економіки. 2017. № 1. Т. 16. С. 41-57.

2. Колодійчук I. А. Засадничі принципи формування системи поводження 3 відходами. Регіональна економіка. 2017. № 2. С. 80-88.

3. Павлов В. І., Павліха Н. В., Скороход І. С. Ефективність використання вторинних ресурсів у регіоні: оцінка та інноваційні механізми : монографія. Рівне, 2007. $155 \mathrm{c}$.

4. Van Buren N., Demmers M., Van der Heijden R., Witlox F. Towards a Circular Economy: The Role of Dutch Logistics Industries and Governments. Sustainability. 2016. Vol. 8. URL: https://www.mdpi.com/2071-1050/8/7/647\#

5. Національна стратегія управління відходами в Україні до 2030 року : Розпорядження Кабінету Міністрів України від 08.11.2017 р. № 820-р. Дата оновлення: 24.12.2019. URL: https://zakon.rada.gov.ua/laws/show/820-2017-\%D1\%80

6. Стан сфери поводження з побутовими відходами в Україні за 2019 рік. Міністерство розвитку громад та територій України, 2020. URL: https://www.minregion.gov.ua/napryamki-diyalnosti/zhkh/terretory/stan-sferypovodzhennya-z-pobutovymy-vi.

7. Частка населених пунктів, у яких впроваджено роздільне збирання ТПВ, у загальній кількості населених пунктів регіону. URL: https://www.minregion.gov.ua/wp-content/uploads/2018/01/Dodatok.pdf

8. Дзюбинська О. В. Механізм використання ресурсного потенціалу побутових відходів регіону на засадах кругової економіки : дис. ... канд. екон. наук: 08.00.05/ Луцький НТ. Луцьк, 2021. 305 с. 